\title{
Apakah Sukuk Ritel Merupakan Ancaman Bagi penghimpunan Dana Pihak Ketiga Pada Bank Syariah?
}

\author{
Muhammad Syakur \\ Fakultas Ekonomi dan Bisnis, Universitas Airlangga, Surabaya \\ Alamat Email: muhammad.syakur-2018@ pasca.unair.ac.id
}

\begin{abstract}
Abstrak: Penelitian ini merupakan penelitian kuantitatif untuk mengetahui dampak penerbitan sukuk ritel terhadap penghimpunan Dana Pihak Ketiga (DPK) pada Bank Syariah di Indonesia padaperiode 2015 - 2019. Data yang digunakan adalah data sekunderdari Laporan Statistik Perbankan Syariahkonsolidasi Bank umum syariah dan Unit usaha syariah serta kemenkeusecara kuartal dengan teknik analisis regresi linear berganda metode Ordinary Least Square (OLS), DPK sebagai variabel terikat sedangkan Sukuk Ritel, ROA, Biaya Promosi, Inflasi dan Bi rate sebagai variabel bebasnya. Hasilnya menunjukkan bahwa Sukuk Ritel memiliki pengaruh negatif dan signifikan terhadap penghimpunan DPK artinya penerbitan sukuk ritel mengakibatkan terjadinya penurunan pada DPK Bank Syariah. Oleh karena itu pemerintah perlu mengkaji kebijakan terkait mekanisme penerbitan sukuk ritel agar bisa bersinergi dengan perkembangan Bank Syariah. Hasil lainnya menunjukkan bahwa ROA dan biaya Promosi berpengaruh positif sedangkanBi rate berpengaruh negatif dan signifikan bagi Penghimpunan DPK Bank Syariah.
\end{abstract}

Kata kunci: Sukuk ritel, Bank Syariah, DPK.

Abstract: This research is a quantitative study that aims to consider the effect of retail sukuk on the collection of third parties funds (TPF) in Indonesian Islamic Banks for 2015 - 2019. The data used are secondary data retrieved from Islamic Banking Statistics Report for shariah commercial and unit shariah bank quarterly. The method is multiple linear regression analysis techniques with Ordinary Least Square (OLS) approach, using TPF as the dependent variable while Retail Sukuk, ROA, Promotion Cost, Inflation and Bi rate as the independent variables. The results shows Retail Sukuk has a negative and significant impact on the collection of TPF which is intended that retail sukuk is causing the decrease of TPF amount in Indonesian Islamic bank. Therefore the Indonesian government needs to review the policies related to retail sukuk issuance in order to synergize with the development of Islamic Banks. Other results indicate that ROA and promotion costs have positive and significant influance for TPF collection in Indonesian Islamic bank while BI rate is the opposite.

Keyword: ritel sukuk, Islamic bank, third parties funds. 


\section{PENDAHULUAN}

Dari tujuh sektor utama pada industri halal global, sektor keuangan Islam masih menjadi penyumbang nilai aset terbesar selama beberapa tahun terakhir. Menurut SGIE Report(Thomson dan Dinar, 2018)nilai aset dari sektor keuangan Islam global mencapai 2,5 Milyar USD pada tahun 2018 dan diprediksi jumlah tersebut akan tumbuh menjadi 3,47 Milyar USD di tahun 2024. Pesatnya pertumbuhan pada sektor tersebut antara lain ditopang oleh dua pilar utama yaitu sektor perbankan Islam dan Sukuk (Mimouni et al., 2019). Keduanyamendominasi industri keuangan Islam di berbagai negara di dunia termasuk Indonesia.

Bank syariah memiliki fungsi sebagai lembaga intermediasi melalui penyaluran pembiayaan dari penempatan dana nasabah pada bank atau pendistribusian dana dari unit surplus ke unit defisit (Saunders \& Cormets, 2010). Sementara sukuk merupakan salah satu instrumen keuangan yang dapat digunakan untuk mendapatkan dana atau modal dalam jumlah yang besar dari para investor(Razak et al., 2019). Dari definisi tersebut menunjukkan bahwa baik bank syariah maupun pihak yang menerbitkan sukuk memiliki tujuan yang sama yakni menghimpun dana dari pihak lain. Sukuk sendiri terdiri dari beberapa macam namun yang dapat diakses secara bebas dan mudah oleh setiap individu adalah sukuk ritel yang diterbitkan oleh pemerintah sejak tahun 2009 dan memiliki fiturfitur unggulan dibanding produk penghimpunan dana dari Bank syariah.Berikut adalah perbandingan perkembangan sukuk ritel dan DPK bank syariah di indonesia

Tabel 1. Perkembangan DPK Pada Bank Syariahdi Indonesia

\begin{tabular}{c|c|c|c|c|c}
\hline Tahun & $\begin{array}{c}\text { DPK } \\
\text { (Milyar) }\end{array}$ & Growth & Tahun & $\begin{array}{c}\text { DPK } \\
\text { (Milyar) }\end{array}$ & Growth \\
\hline 2009 & 52,271 & $48 \%$ & 2015 & 231,175 & $6 \%$ \\
\hline 2010 & 76,036 & $45 \%$ & 2016 & 279,335 & $21 \%$ \\
\hline 2011 & 115,415 & $52 \%$ & 2017 & 334,719 & $20 \%$ \\
\hline 2012 & 147,512 & $28 \%$ & 2018 & 371,828 & $11 \%$ \\
\hline 2013 & 183,534 & $24 \%$ & 2019 & 416,558 & $12 \%$ \\
\hline 2014 & 217,858 & $19 \%$ & \multicolumn{4}{|l}{}
\end{tabular}

Sumber: (Laporan SPS OJK, 2009-2019)

Pada Tabel 1 menunjukkan bahwa secara volume nilai Dana Pihak Ketiga (DPK) pada Bank syariah di Indonesia gabungan antara BUS dan UUSpada periode 2009-2019 menunjukkan pertumbuhan yang positif tetapi mengalami tren yang cenderung menurun terutama lima tahun terakhirdan jika dilihat dari besar market sharenya pun tidak mengalami perubahan yang signifikan, yakni berkisar di angka 5\% saja(OJK, 2018). Sementara itu, disaat bersamaan pemerintah Indonesia juga rutin mengeluarkan sukuk ritel setiap tahunnya. Berikut datanya 
Tabel 2. Perkembangan Penerbitan Sukuk Ritel di Indonesia

\begin{tabular}{c|c|c|c|c|c|c|c}
\hline Tahun & $\begin{array}{c}\text { Nomor } \\
\text { Seri }\end{array}$ & $\begin{array}{c}\text { Nilai } \\
\text { (Milyar) }\end{array}$ & $\begin{array}{c}\text { Outstanding } \\
\text { Sukuk Ritel } \\
\text { (Milyar) }\end{array}$ & Tahun & $\begin{array}{c}\text { Nomor } \\
\text { Seri }\end{array}$ & $\begin{array}{c}\text { Nilai } \\
\text { (Milyar) }\end{array}$ & $\begin{array}{c}\text { Outstanding } \\
\text { Sukuk Ritel } \\
\text { (Milyar) }\end{array}$ \\
\hline 2009 & SR-001 & 5,556 & 5,556 & 2015 & SR-007 & 21,965 & 56,257 \\
\hline 2010 & SR-002 & 8,034 & 13,590 & 2016 & SR-008 & 31,500 & 72,788 \\
\hline 2011 & SR-003 & 7,341 & 20,932 & 2017 & SR-009 & 14,037 & 67,502 \\
\hline 2012 & SR-004 & 13,614 & 28,989 & 2018 & SR-010 & 8,437 & 53,974 \\
\hline 2013 & SR-005 & 14,969 & 35,924 & 2019 & SR-011 & 21,118 & 43,591 \\
\hline 2014 & SR-006 & 19,323 & 47,906 & & & &
\end{tabular}

Sumber: (Kemenkeu, 2009-2019)

Pada Tabel 2 terlihat bahwa dari tahun 2009 sampai dengan tahun 2019 pemerintah telah mengeluarkan setidaknya 11 seri sukuk ritel dengan nilai atau volume outstandingtelah mencapai 10\% dari total DPK Bank syariah di Indonesia. Sementara itu, Jika ditelaah lebih jauh penurunan DPK biasanya terjadi pada kuartal 1 setiap tahunnya saat sukuk ritel diterbitkan, lantas adakah keterkaitan diantara keduanya?. Beberapa penelitian sebelumnya telah membahas mengenai hubungan antara Sukuk dan Bank syariah secara umum, beberapa diantaranya adalah sebagai berikut :

(Smaoui et al.,2017), membahas tentang hubungan antara sukuk market dan bankmarket(konvensional dan syariah) pada periode 1995-2015 dari segi financingdengan teknik GMM estimator, hasilnya menunjukkan bahwa sukuk merupakan subtitusi untuk bank syariah. sementara itu (Mimouni et al., 2019)meneliti pengaruh sukuk terhadap performance bank syariahdan bank konvensional dari 13 negara periode 2003-2014 dengan dinamic data panel, hasilnya menunjukkan bahwa issuance sukuk menyebabkan terjadinya penurunan laba pada bank syariah. Selanjutnya, (Smaoui dan Ghouma, 2020) meneliti tentang pengaruh sukuk market terhadap capital ratio pada Bank Syariah periode 2005-2014, hasilnya menunjukkan bahwa sukuk memiliki pengaruh negatif terhadap rasio modal bank syariah. Adapun penelitian yang spesifik membahas hubungan antara sukuk ritel dengan penghimpunan DPK pada bank syariah di Indonesiabarudilakukan oleh (Yaya dan Sofiyana, 2018)dengan menggunakan faktor internal (Ukuran perusahaan, jumlah kantor,tingkat bagi hasil) dan faktor eksternal (Sukuk ritel, Inflasi dan Bi rate) sebagai variabel bebasnya. Namun, Penelitian tersebut menggunakan data sampel pada periode yang relatif singkat yaitu tahun 2012 - 2015 secara kuartal dan hanya menggunakan data bank umum syariah saja.

Penelitian ini akan mengisi gaptersebut, peneliti akan meneliti secara empirik apakah sukuk ritel merupakan ancaman bagi penghimpunan DPK pada Bank Syariah di Indonesia dengan menggunakan data sampel dengan periode lebih panjang yakni dari tahun 2015-2019 secara triwulanan dan untuk nilai DPK yang digunakan tidak hanyadari bank umum syariah saja tetapi juga dari unit usaha syariah. Selain itu, untuk faktor internal yang menjadi variabel bebasnya peneliti menggunakan variabel profitabilitas yan dan biaya promosi. Dengan data yang lebih banyak dan terbaru serta penggunaan variabel bebas yang berbeda diharapkan dapat memberikan hasil penelitian yang lebih valid serta 
menambah literatur empirikal terkait hubungan antara sukuk dan bank yang jumlahnya masih terbatas (Mimouni et al., 2019).

\section{KAJIAN TEORI}

Sukuk Ritel dan DPK Bank Syariah. Sukuk Ritel adalah produk surat berharga syariah negara yang ditertbitkan oleh pemerintah republik Indonesia dalam hal ini kementerian keuangan dan dijual kepada individu atau perseorangan warga negara Indonesia melalui agen penjual di pasar perdana dalam negeri (Kemenkeu, 2020). Tujuan pemerintah menerbitkan sukuk ritel setidaknya ada empat yaitu : instrumen pembiayaan baru untuk anggaran negara, meningkatkan jumlah investor domestik, mendukung perekembangan sektor keuangan Islam di Indonesia, dan memperkuat pasar modal Indonesia dengan mentransformasi masyarakat yang saving oriented menjadi investing oriented(Sukmana, 2019). Sementara itu, keuntungan yang dapat diperoleh oleh para investor dari sukuk ritelmenurut kemenkeu adalah sebagai berikut : Pokok dan Imbalan di jamin oleh negara, tingkat imbalan kompetitif atau lebih tinggi dari rata-rata tingkat bunga deposito Bank BUMN, tingkat Imbalan tetap, imbalan dibayar tiap bulan, dapat diperdagangkan di pasar sekunder antar investor domestik, cukup dengan satu juta masyarakat sudah bisa berinvestasi di Sukuk ritel, mendukung pembiayaan nasional, dan akses investasi sesuai prinsip syariah(Kemenkeu, 2020). Sukuk ritel diterbitkan pemerintah sejak tahun 2009 dan rutin setiap tahunnya, per tahun 2019 telah memasuki seri 11 (Tabel 2). Terkait tingkat imbalan setiap seri sukuk dan perkembangan jumlah investornya dapat dilihat pada tabel dibawah ini

Tabel 3. Perkembangan Imbal Sukuk dan Jumlah Investornya

\begin{tabular}{c|c|c}
\hline Nomor seri sukuk & Imbalan & Total Investor \\
\hline SR-001 & $12.00 \%$ & 14,295 \\
\hline SR-002 & $8.7 \%$ & 17,231 \\
\hline SR-003 & $8.15 \%$ & 15,847 \\
\hline SR-004 & $6.25 \%$ & 17,606 \\
\hline SR-005 & $6.00 \%$ & 17,783 \\
\hline SR-006 & $8.75 \%$ & 34,692 \\
\hline SR-007 & $8.25 \%$ & 29,706 \\
\hline SR-008 & $8.3 \%$ & 48,444 \\
\hline SR-009 & $6.9 \%$ & 29,838 \\
\hline SR-010 & $5.9 \%$ & 17,992 \\
\hline SR-011 & $8.05 \%$ & 35,026 \\
\hline S
\end{tabular}

Sumber: (Kemenkeu, 2009-2019)

Pada tabel 3 diatas menunjukkan dari segi imbalan sukuk ritel berada dikisaran 5.9\% - 12\% . nilai tersebut lebih tinggi dibanding rata-rata imbala bagihasil simpanana pada bank syariah yang berada dikisaran 4\%-5\%(OJK, 2018). Selain itu, pada tabel 3 menggambarkan kecenderungan peningkatan jumlah investor sukuk ritel terutama pada saat imbal bagi hasilnya meningkat. 
Sementara itu.simpanan pada bank didefinisikan sebagai sejumlah uang yang disimpan oleh para nasabah dalam account miliknya di bank baik dalam bentuk tunai. cek ataupun yang dikirim melalui transfer(Mushtaq dan Siddiqui, 2017). Simpanan tersebut kemudian disebut juga dengan Dana Pihak Ketiga atau dana masyarakat karena merupakan dana yang dihimpun oleh bank yang berasal dari masyarakat dalam arti luas. meliputi masyarakat individu, maupun badan usaha dalam bentuk tabungan, giro atau deposito. Adapun Simpanan atau DPK pada Bank syariah Menurut Undang-Undang No.21Tahun 2008 tentang perbankan syariah (Pasal 1) adalahdana yang dipercayakan oleh Nasabah kepada bank syariah dan/atau unit usaha syariah(UUS) berdasarkan akad wadiah atau akad lain yang tidak bertentangan dengan prinsipsyariah dalam bentuk giro. tabungan. atau bentuk lainnya yang dipersamakan denganitu. DPK merupakan penggerak dari sektor perbankan karena merupakan sumber dana terbesar bagi bank yang berkisar 80\% - 90\% dari dana yang dikelola oleh bank (Dendawijaya, 2009).

Menurut penelitian yang dilakukan oleh (Said dan Ali, 2016) portofolio simpanan pada Bank Syariah di Indonesia di dominasi oleh simpanan yang memberikan bagi hasil atau berakad Mudharabah. hal tersebut mengindikasikan bahwa nasabah bank syariah sangat memperhatikan aspek return yang diberikan oleh Bank.Sementara itu. penelitian yang dilakukan oleh (Smaoui et al.,2017) menunjukkan bahwa penerbitan Sukuk merupakan subtitusi atau pengganti dari produk produkperbankan terutama pada negaranegara yang Banknya memiliki peran yang besar dalam perekonomian.

Berdasarkan penjelasan-penjelasan tersebut menunjukkan adanya potensi persaingan antara sukuk ritel dan produk-produk penghimpunan DPK pada Bank syariah di Indonesia sehingga menjadi landasan peneliti pada hipotesis berikut :

H1 : Sukuk Ritel berpengaruh negatif dan signifikan terhadap Penghimpunan Dana Pihak Ketiga Pada Bank Syariah di Indonesia

Profitability dan Biaya Promosi.ROA (Return of asset)merupakan salah satu indikator utama dalam mengukur tingkat profitability pada sebuah bank yang diperoleh dengan cara membagi antara nilai net income dengan total aset (Rose \& Hudgins, 2010). Selain itu,ROA adalah rasio yang paling banyak digunakan untuk mempelajari dan menganalisa performance suatu Bank (Sufian, 2011). Bagi bank syariah, semakin besar profit yang dihasilkan tentunya makin besar pula bagi hasil yang bisa dinikmati oleh pasa deposan atau penyimpan dana sehingga semakin besar profitabilitas suatu bank syariah maka akan menarik minat nasabah untuk menyimpan dananya. Berikut perkembangan nilai ROA pada bank syariah di Indonesia periode 2015-2019 per kuartal : 
Gambar 1. Perkembangan ROA Bank Syariah di Indonesia

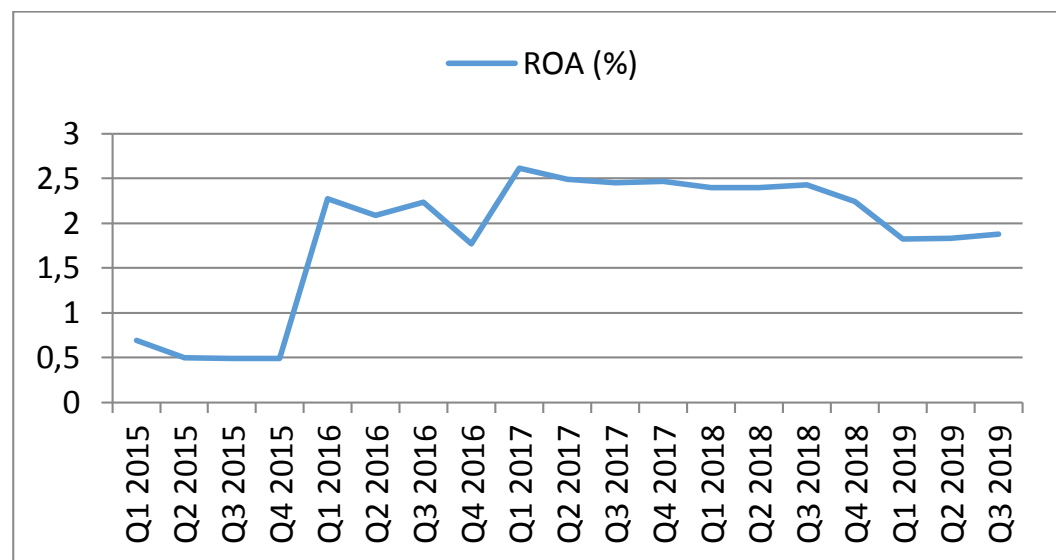

Sumber: (Laporan SPS OJK, 2015-2019)

Pada gambar diatas terlihat bahwa nilai ROA selama lima tahun terakhir memiliki tren peningkatan dengan nilai berkisar antara 0.5 sampai $3 \%$. Sementara itu, hubungan antara ROA dan DPK telah dibuktikan secara empirik melalui beberapa penelitian antara lain yang dilakukan oleh(Susanti, 2015) yangmenunjukkan adanya hubungan yang positifdan signifikan antara tingkat keuntungan pada bank syariahdengan penghimpunan DPK pada Bank Syariah.Berdasarkan hal tersebut peneliti kemudian membuat Hipotesis sebagai berikut

\section{H2 :ROA berpengaruh Positif dan signifikan terhadap DPK Bank Syariah di Indonesia}

Di sisi lain, faktor internal yang dianggap memiliki pengaruh terhadap peningkatan DPK pada bank adalah promosi yang merupakan suatu metode yang dilakukan untuk memberikan informasi terkait suatu produk agar mampu diterima oleh konsumen (Kincaid, 2003). Dalam industri perbankan syariah, promosi memiliki peran yang sangat penting dalam meningkatkan jumlah nasabahnya(Al-Sharif et al., 2017). Berikut perkembangan Biaya promosi yang dikeluarkan bank syariah di Indonesia periode 20152019 per kuartal :

Gambar 2. Perkembangan Biaya Promosi Bank Syariah di Indonesia

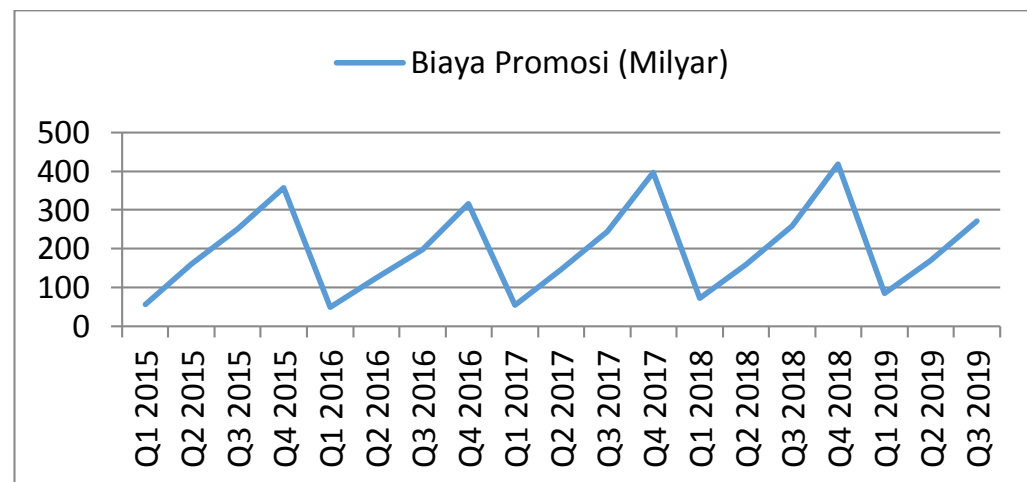

Sumber: (Laporan SPS OJK, 2015-2019) 
Pada gambar diatas menunjukkan bahwa biaya promosi yang dikelurkan oleh bank syariah di Indonesia cenderung fluktuatif dengan kisaran 100 sampai 400 milyar perkuartalnya. Sementara itu, secara empirik menurut penelitian yang dilakukan oleh (AlSharif et al., 2017) kenaikan biaya promosi yang dikeluarkan oleh bank syariah akan berdampak pada kenaikan nilai DPK.Berdasarkan penjeasan-penjelasan tersebut peneliti membuat Hipotesis sebagai berikut

H3 : Biaya Promosi berpengaruh Positif dan signifikan terhadap DPK Bank Syariah di Indonesia

Inflasi dan Bi rate.Menurut Bank Indonesia inflasi adalah keadaan ekonomi dimana terjadi kenaikan harga harga barang secara umumdan terus menerus dalam jangka waktu tertentu.Adanya kenaikan harga tersebutmenyebabkan konsumen harus mengeluarkan lebihbanyak uang untuk mendapatkan barangmaupun jasa yang samasehingga porsi uang yang dimiliki oleh rumah tangga untuk saving akan berkurang seiring terjadinya inflasimenurut Dalton dalam (Dash dan Kumar, 2018). Berikut perkembangan inflasi di Indonesia periode 2015-2019 per kuartal:

Gambar 3. PerkembanganInflasi di Indonesia

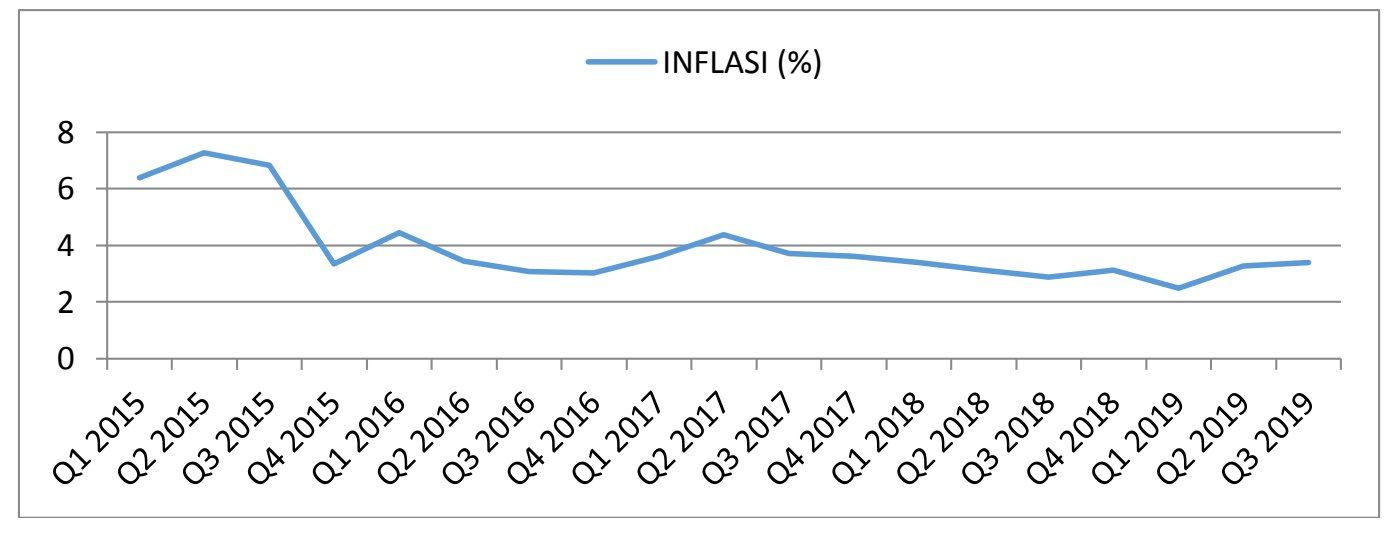

Sumber: (Laporan SPS OJK, 2015-2019)

Penelitian-penelitian sebelumnya yang membahas adanya hubungan negatif antara Inflasi dan simpanan antara lain dilakukan oleh (Bascand et al.,1997)dan (Acunto et al.,2015).Sementara penelitian pada Bank syariah di Indonesia juga menunjukkan hubungan negatif signifikan antara kedua variable tersebut(Abduh et al., 2011). Berdasarkan uraian tersebut peneliti membuat Hipotesis sebagai berikut

\section{H4 :Inflasi berpengaruh Negatif dan signifikan terhadap DPK Bank Syariah di Indonesia}

Sementara itu.variabel makroekonomi lain yang dianggap berpengaruh terhadap penghimpunan DPK adalah Bi rate yang didefinisikan sebagaisuku bunga kebijakan yang mencerminkan sikap atau stance kebijakan moneter yang ditetapkan Bank Indonesia dan diumumkan kepada publik. Suku bunga ini kemudian akan mempengaruhi suku bunga 
simpanan dan kredit pada perbankan(Afrida dan Iskandar, 2018).Berikut perkembangan BI rate di Indonesia periode 2015-2019 per kuartal:

Gambar 4. Perkembangan Bi rate di Indonesia

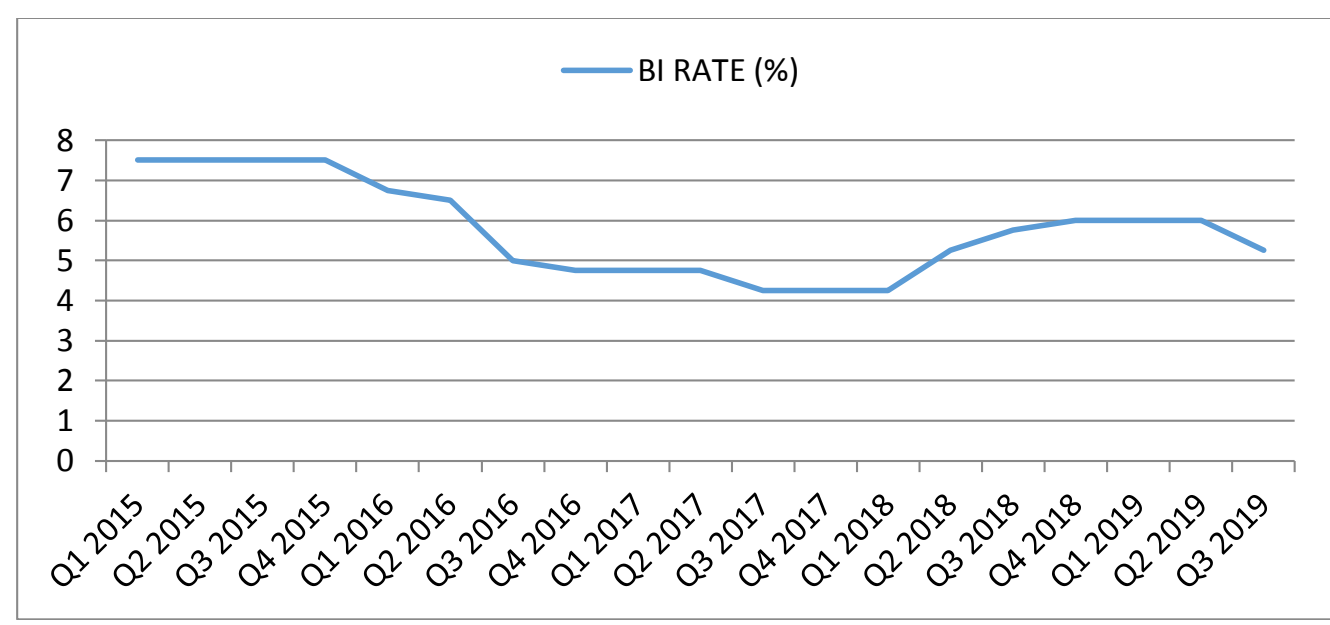

Sumber: (Laporan SPS OJK, 2015-2019)

Pada gambar diatas menunjukkan bahwa BI rate di Indonesia memiliki trend menurun pada periode 2015-2019 dengan nilai antara 4 sampai $8 \%$. Penelitian yang dilakukan oleh (Demiralp, 2015)menunjukkan bahwa deposan pada bank syariah di negara yang menganut dualbanking systemcenderung bersifat rasional terhadap perubahan suku bungaartinya ketika naik mereka akan berpikir untuk menarik dananya dari bank syariah dan menyimpannya pada bank konvensional karena kan mendapatkan return yang lebih tinggi.Berdasarkan uraian tersebut peneliti membuat Hipotesis sebagai berikut

H5 : Bi rate berpengaruh Negatif dan signifikan terhadap DPK Bank Syariah di Indonesia

Hubungan atau keterkaitan antar hipotesis-hipotesis tersebut diatas kemudian dinyatakan dalam sebuah framework conceptual model seperti yang ditunjukkan pada gambar 2 dibawah ini. Dimana simbol x adalah variabel bebas atau independen yang terdiri atas : Sukuk ritel. ROA.Biaya Promosi. Inflasi dan Bi Rate. Sedangkan simbol yadalah variabel tidak bebasnya atau variabel terikat yaitu DPK pada bank syariah di Indonesia 
Gambar 5. Conceptual Model

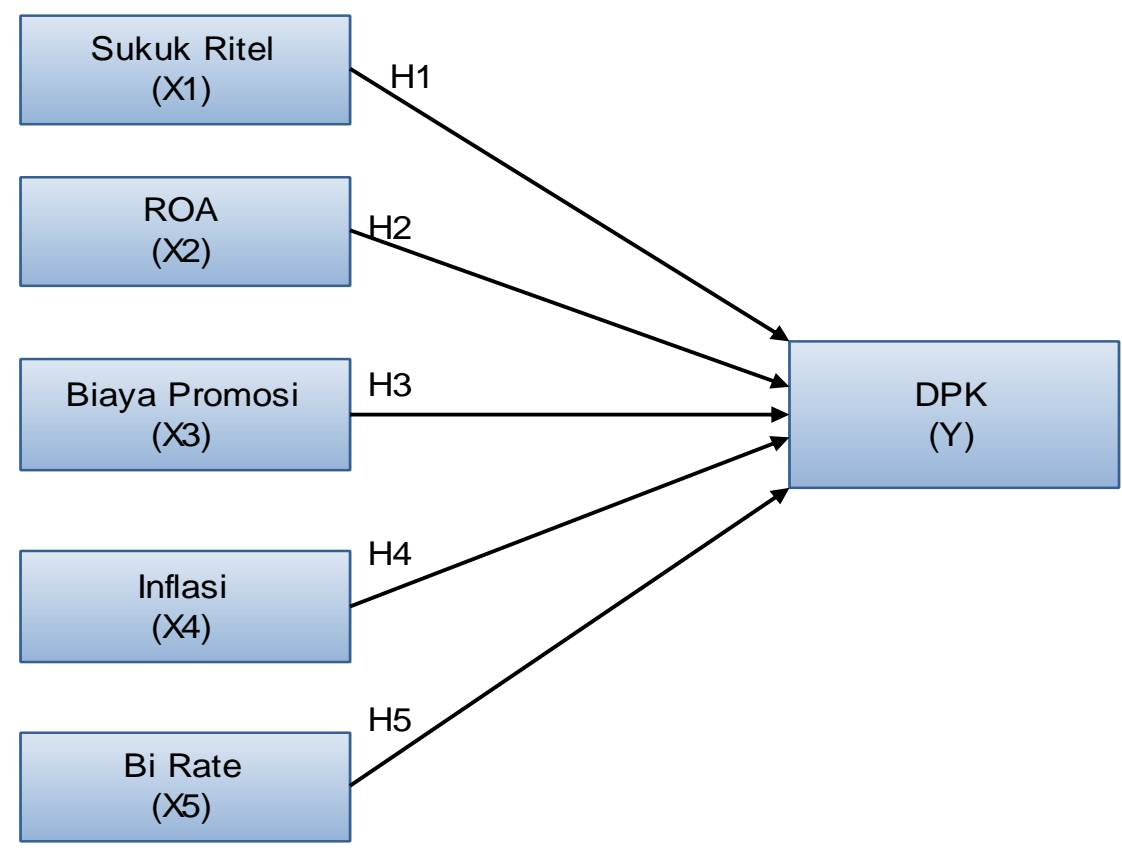

Defenisi Variabel

Tabel 4. Definisi Variabel

\begin{tabular}{|c|c|c|}
\hline Variabel & Defenisi operasional & Keterangan \\
\hline $\begin{array}{l}\text { Sukuk Ritel } \\
\text { (X1) }\end{array}$ & $\begin{array}{l}\text { Jumlah Oustanding Sukuk Ritel } \\
\text { dari seri SR-007 sampai dengan } \\
\text { seri SR-011 }\end{array}$ & $\begin{array}{l}\text { Karena satuan milyar rupiah } \\
\text { maka dilakukan logaritma } \\
\text { natural (Ln) }\end{array}$ \\
\hline $\begin{array}{l}\mathrm{ROA} \\
(\mathrm{X} 2)\end{array}$ & $R O A=\frac{\text { Laba Sebelum Pajak }}{\text { Rata-Rata Total Assets }} \times 100 \%$ & Satuan persen \\
\hline $\begin{array}{l}\text { Biaya Promosi } \\
\text { (X3) }\end{array}$ & $\begin{array}{l}\text { Jumlah Biaya promosi pada } \\
\text { neraca BUS dan UUS }\end{array}$ & $\begin{array}{l}\text { Karena satuan milyar rupiah } \\
\text { maka dilakukan logaritma } \\
\text { natural (Ln) }\end{array}$ \\
\hline $\begin{array}{l}\text { Inflasi } \\
\text { (X4) }\end{array}$ & Tingkat inflasi per kuartal & Satuan persen \\
\hline $\begin{array}{l}\text { Bi rate } \\
\text { (X5) }\end{array}$ & $\begin{array}{l}\text { Tingkat suku bunga acuan yang } \\
\text { ditetapkan oleh Bank Indonesia }\end{array}$ & Satuan persen \\
\hline
\end{tabular}


DPK $(\mathrm{Y})$
Jumlah total DPK ( Deposito + Giro + Tabungan) pada BUS dan UUS konsolidasi
Karena satuan milyar rupiah maka dilakukan logaritma natural (Ln)

\section{METODOLOGI}

Penelitian ini menggunakan data sekunder yang diperoleh dari berbagai sumber. Untuk data DPK. ROA dan Biaya Promosi diperoleh dari laporan Satistik Perbankan Syariah OJK gabungan BUS dan UUS. Data sukuk ritel diperoleh dari website kemenkeu. sedangkan data Bi rate dan inflasi diperoleh dari Bank Indonesia dan BPS. Semua data tersebut bersifat triwulanan atau perkuartaldimulai dari Q1 2015 sampai dengan Q3 2019 sehingga merupakan data time series dengan total 19 observasi.

Penelitian ini menggunakan metode regresi linear berganda dengan pendekatan OLS(Ordinary Least Square)dan menggunakan software Eviews 10. untuk pengujian datanyaterdiri dari beberapa tahapan. yaitu uji asumsi klasikyang meliputi uji normalitas. uji multikolinearitas. uji Heteroskedastisitas dan uji autokorelasi. Setelah itu dilakukan regresi dan interpretasi hasilc. Adapun persamaan regresi yang digunakan adalah sebagai berikut

$$
\operatorname{Ln} \mathrm{Y}=\alpha-\operatorname{Ln} \beta_{1} \mathrm{X} 1+\beta_{2} X 2+\beta_{3} \operatorname{LnX} 3-\beta_{4} X 4-\beta_{5} X 5+\mathrm{e}
$$

Keterangan :

Y : DPK Bank Syariah

X1 : Outstanding Sukuk Ritel

$\mathrm{X} 2$ : ROA

$\mathrm{X} 3$ : Biaya Promosi

$\mathrm{X} 4$ : Inflasi

X5 : BI Rate

\section{HASIL DAN DISKUSI}

\section{Uji Asumsi klasik}

Uji Normalitas. Pengujian Normalitas pada model regresi OLS dilakukan pada residualnya. Salah satu metode pengujiannya dengan Jarque-Bera jika nilai Jarque-Bera < 2 dan Prob > 0.05 maka residual berdistribusi normal. Pada pengujian dengan software eviews 10 diperoleh nilai Jarque-Bera $=0.91$ dan Prob $=0.633$ sehingga residual model telah berdistribusi normal.

Uji Multikolinearitas.Suatu model regresi dikatakan terkena atau mengandung Multikolinearitas jika terjadi hubungan linearitas diantara beberapa atau semua variabel bebas pada model regresi sehingga sulit untuk melihat pengaruh variable penjelas terhadap variabel yang dijelaskan(Nachrowi, 2002).Salah satu metode yang digunakan untuk menguji multikolinearitas pada suatu model bisa dilakukan dengan melihat nilai 
VIF(Variance Inflation Factor). Jika nilai VIF > 10 maka model tersebut dianggap tidak mengandung Multikolinearitas.Berikut hasil pengujiannya

Tabel 5. Hasil Uji Multikolinearitas

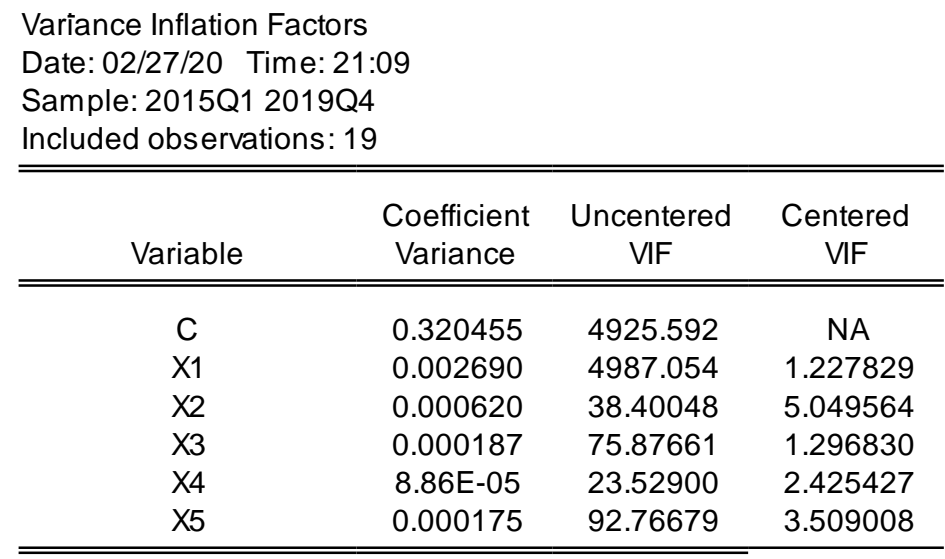

Sumber: (Eviews 10, 2020)

Berdasarkan tabel diatas terlihat bahwa semua variabel memiliki nilai Centered VIF > 10sehingga dapat disimpulkan bahwa tidak terdapat masalah multikolinearitas pada model regresi.

Uji Heteroskedastisitas. Heteroskedastisitasdapat membuat prosedur pengujian hipotesis nilainya diragukan atau tidak valid. Oleh karena itu jika suatu model terkena Heteroskedastisitasdiperlukan suatu tindakan perbaikan pada model regresi untuk menghilangkanHeteroskedastisitas tersebut. Salah satu cara untuk menguji Heteroskedastisitas pada model regresi adalah dengan menggunakan uji Breusch-Pagan. jika nilai $\mathrm{p}>0.05$ maka disimpulkan tidak terjadi Heteroskedastisitas pada model. Berikut hasil pengujiannya

Tabel 6. Hasil Uji Heteroskedastisitas

\begin{tabular}{l} 
Hetēroskedasticity Test: Breusch-Pagan-Godfrey \\
Null hypothesis: Homoskedasticity \\
\hline \hline
\end{tabular}

Sumber: Eviews 10

Berdasarkan tabel diatas menunjukkan nilai $\mathrm{p}=0.0644>0.05$ sehingga model ini bisa dikatakan homoskedastisitas atau tidak terjadi Heteroskedastisitas. 
Uji Autokorelasi. Uji autokorelasi dilakukan untuk mengetahui korelasi variabel yang ada didalam model prediksi dengan perubahan waktu. Dalam sebuah analisis regresi tidak boleh ada korelasi antara observasi suatu periode dengan observasi periode sebelumnya. Untuk melakukan pengujian autokorelasi bisa dilakukan dengan melakukan uji LM (Lagrange Multiplier). Jika nilai $\mathrm{p}>0.05$ maka disimpulkan tidak terjadi autokorelasi pada model. Berikut hasil pengujian

Tabel 7. Hasil Uji Autokorelasi

Breüsch-Godfrey Serial Correlation LM Test:

Null hypothesis: No serial correlation at up to 2 lags

\begin{tabular}{llll}
\hline \hline & & & \\
F-statistic & 0.527140 & Prob. F(2,11) & 0.6045 \\
Obs ${ }^{*}$ R-squared & 1.661759 & Prob. Chi-Square(2) & 0.4357 \\
\hline
\end{tabular}

Sumber: (Eviews 10, 2020)

Hasil uji LM pada tabel diatas menunjukkan bahwa nilai $\mathrm{p}=0.4357>0.05$ sehingga tidak terjadi autokorelasi. Selain itu, jika menggunakan uji dw (Durbin Watson) maka nilai $\mathrm{dw}$ pada model regresi adalah 1.75 yangberada diantara du dan $4-\mathrm{du}$.

\section{Interpretasi Model(Hasil Uji t dan Uji F)}

Tabel 8. Hasil Regresi Linear

\begin{tabular}{|c|c|c|c|c|}
\hline Variable & Coefficient & Std. Error & t-Statistic & Prob. \\
\hline C & 21.56290 & 0.566087 & 38.09113 & 0.0000 \\
\hline$\times 1$ & -0.849379 & 0.051864 & -16.37693 & 0.0000 \\
\hline$\times 2$ & 0.168663 & 0.024896 & 6.774827 & 0.0000 \\
\hline$\times 3$ & 0.065684 & 0.013669 & 4.805429 & 0.0003 \\
\hline$\times 4$ & -0.014684 & 0.009412 & -1.560180 & 0.1427 \\
\hline$\times 5$ & -0.041255 & 0.013223 & -3.120009 & 0.0081 \\
\hline R-squared & 0.980887 & \multirow{7}{*}{\multicolumn{2}{|c|}{$\begin{array}{l}\text { Mean dependent var } \\
\text { S.D. dependent var } \\
\text { Akaike info criterion } \\
\text { Schwarz criterion } \\
\text { Hannan-Quinn criter. } \\
\text { Durbin-Watson stat }\end{array}$}} & 12.59036 \\
\hline Adjusted R-squared & 0.973536 & & & 0.216125 \\
\hline S.E. of regression & 0.035159 & & & -3.605809 \\
\hline Sum squared resid & 0.016070 & & & -3.307565 \\
\hline Log likelihood & 40.25518 & & & -3.555334 \\
\hline F-statistic & 133.4352 & & & 1.756370 \\
\hline Prob(F-statistic) & 0.000000 & & & \\
\hline
\end{tabular}

Sumber: (Eviews 10, 2020)

Hasil Uji F. Berdasarkan tabel 9 diatas nilai F-statistic adalah 133.4 dan Prob F-Statistik bernilai 0.0000 sehingga menunjukkan bahwa variabel independen yaitu Sukuk Ritel(X1), ROA (X2), Biaya Promosi (X3), Inflasi (X4), dan Bi rate (X5) berpengaruh secara 
simultan atau bersama-sama terhadap variabel dependen (DPK) pada bank syariah di Indonesia

Hasil Uji t. Pada tabel 9 menunjukkan dari 5 variabel independen yang digunakan pada model yang berpengaruh secara signifikan ada 4variabel yaitu Sukuk Ritel (X1), ROA (X2), Biaya Promosi (X3), dan Bi rate (X5) sementara Inflasi (X4) tidak signifikan. Jika dibandingkan dengan hipotesis yang telah dibuat pada penelitian ini hasilnya sebagai berikut

Tabel 9. Perbandingan Hipotesis dan Hasil Regresi

\begin{tabular}{l|c|c|c}
\hline \multicolumn{1}{c|}{ Variabel } & Hipotesis & Hasil regresi & Keterangan \\
\hline Sukuk Ritel & - & - & Diterima \\
\hline ROA & + & + & Diterima \\
\hline Biaya Promosi & + & + & Diterima \\
\hline Inflasi & - & Tidak Signifikan & Ditolak \\
\hline Bi rate & - & - & Diterima \\
\hline
\end{tabular}

Pada hipotesis 1 peneliti menduga adanya penerbitan Sukuk Ritel yang dilakukan oleh pemerintah Indonesia berpengaruh negatif dan signifikan terhadap penghimpunan DPK pada Bank Syariah. Hasil regresi linear menunjukkan hasil yang sama dengan nilai koefisien -0.849 dan Prob adalah 0.000yang artinya setiap kenaikan nilai sukuk ritel sebesar $1 \%$ maka akan menurunkan nilai DPK pada bank syariah sebesar $0.849 \%$ dengan syarat ceteris paribus sehingga hipotesis 1 diterima. Hasil tersebut sejalan dengan hasil penelitian terdahulu yang dilakukan oleh (Smaoui et al., 2017)yang menyatakan bahwa penerbitan sukuk merupakan rival dan subtitusi bagi produk perbankan syariah artinya semakin banyak sukuk yang di issuancetermasuk didalamnya sukuk ritel maka akan berdampak pada terjadinya penurunan penetrasi produk perbankan syariah yang pada akhirnya akan memperkecil market sharenya atau dalam konteks DPK nilainya akan mengalami penurunan

Hal tersebut juga memperkuat hasil penelitian sebelumnya yang dilakukan (Yaya dan Sofiyana, 2018)yang menunjukkan bahwa penerbitan sukuk ritel merupakan ancaman bagi pertumbuhan DPK pada bank syariah di Indonesia karena memiliki captive market yang sama serta dikarenakan karakteristik suku ritel yang memiliki keunggulan dibanding produk DPK Bank Syariah seperti rata-rata imbalan yang lebih tinggi, lebih aman karena dijamin oleh negara sehingga resiko lebih kecil. Disisi lain, mayoritas tipe nasabah bank baik bank syariah maupun bank konvensional secara umum adalah nasabah yang rasional, artinya nilai imbalan atau tingkat bagi hasil menjadi perhatian utama nasabah dalam menyimpan atau mengivestasikan dananya(Demiralph, 2015) sehingga tidaklah mengherankan jika banyak nasabah bank syariah akan beralih untuk menginvestasikan dana yang dimiliki pada sukuk ritelkarena menawarkan hasil yang lebih baik

Pada hipotesis 2 peneliti menduga ROA yang merepresentasikan tingkat probabilitas memiliki pengaruh Positif dan signifikan terhadap penghimpunan DPK pada Bank Syariah. Hasil regresi linear menunjukkan bahwa ROA memiliki hubungan yang positif dan signifikanterhadap penghimpunan DPK pada bank syariah dengan nilai koefisien sebesar 0.168 dan Prob adalah $0.000<$ dari nilai $\alpha=0.05$ sehingga hipotesis 2 diterima. Hal tersebut sejalan dengan hasil penelitian-penelitian sebelumnya yang dilakukan 
oleh(Susanti, 2015)dan (Akhtar et al., 2017)yang menyatakan bahwa kenaikan profitabilitas atau tingkat keuntungan pada bank syariah akan berdampak secara langsungterhadap peningkatan jumlah DPK.

Pada hipotesis 3 peneliti menduga Biaya Promosi memiliki pengaruh yang Positif dan signifikan terhadap DPK Bank Syariah. Hasil regresi menunjukkan hasil yang sama dengan koefisien 0.065 dan nilai $\mathrm{p}=0.0003<$ dari nilai $\alpha=0.05$ artinya setiap kenaikan Biaya Promosi sebesar 1\% maka akan menaikkan nilai DPK sebesar $0.065 \%$ sehingga hipotesis 3 diterima.Hasil ini sejalan dengan penelitian-penelitian sebelumnya(Lestari, 2009; Al-Sharif et al., 2017)yang menunjukkan bahwa kenaikan biaya promosi memiliki pengaruh yang positif terhadap peningkatan DPK pada Bank Syariah.

Pada hipotesis 4 peneliti menduga inflasi memiliki pengaruh yang negatif dan signifikan terhadap DPK Bank Syariah di Indonesia. Hasil regresi menunjukkan pengaruh negatif dengan koefisien -0.014 namun tidak signifikankarena nilai $\mathrm{p}=0.0142>$ dari nilai $\alpha=0.05$ sehingga hipotesis 4 ditolak. Hal ini berlawanan dengan hasil penelitian Abduh et al. (2011)dan Acunto et al. (2015)namun sejalan dengan penelitian (Sutono dan Kefi, 2012) yang menyatakan bahwa inflasi tidak memiliki pengaruh yang signifikan terhadap DPK bank Syariah di Indonesia.

Pada hipotesis 5 peneliti menduga Bi Rate memiliki pengaruh yang negatif dan signifikan terhadap DPK Bank Syariah di Indonesia.Hasil regresi menunjukkan hasil yang sama dengan koefisien -0.041 dan nilai $p=0.008<$ dari nilai $\alpha=0.05$ sehingga hipotesis 5 diterima.Hasil ini mendukung penelitian terdahulu yang dilakukan oleh (Demiralp, 2015)dan (Aysan et al.,2018)yang menyatakan bahwa ketika suku bunga naik maka akan mempengaruhi keputusan deposan di Bank Syariah untuk menarik dananya dan memindahkannya ke bank konvensional

Hasil Uji Koefisien Determinasi. Pengujian ini dilakukan untuk mengetahui sejauh mana varibel bebas yang digunakan pada model dalam menjelaskan varibel terikat yang dinyatakan dengan nilai $r$-squared. Hasil uji pada tabel 7 menunjukkan nilai $r$-squared sebesar 0.98. Angka tersebut menunjukkan bahwa variabel sukuk ritel, ROA, biaya promosi, inflasi dan BI rate mampu menjelaskan variabel DPK sebesar $98 \%$ sementara $2 \%$ dijelaskan atau dipengaruhi oleh variabel bebas yang berada diluar model.

\section{KESIMPULAN}

Penelitian ini bertujuan untuk menganalisa secara empirik hubungan antara Penerbitan Sukuk ritel oleh pemerintah dengan Penghimpunan Dana Pihak Ketiga Pada Bank Syariah di Indonesia. Hasilnya menunjukkan bahwa sukuk ritel merupakan rival atau ancaman bagi produk-produk DPK Bank Syariah sehingga merupakan salah satu faktor penyebab menurunnya pertumbuhan DPK Bank Syariah di Indonesia. Oleh karena itu, pemerintah perlu mengkaji ulang kebijakan terkait penerbitan sukuk ritel diantaranya terkait tingkat imbalan, batas minimum dan maksimal pembelian sehingga nasabah bank syariah lebih dibatasi untuk beralih ke sukuk ritel. Disisi lain, dengan adanya penerbitan sukuk ritel oleh pemerintah justru diharapkan mampu untuk menarik minat investor investor yang belum menggunakan produk keuangan syariah untuk beralih.Hasil penelitian ini juga menunjukkan bahwa Bank syariah harus mampu untuk membuat 
inovasi-inovasi produk penghimpunan DPK sehingga mampu bersaing dengan keunggulan-keunggulan yang dimiliki oleh Sukuk Ritel

Temuan lainnya menunjukkan bahwa faktor internal dari Bank syariah seperti tingkat profitabilitas dan kenaikan biaya promosi memiliki pengaruh positif terhadap Penghimpunan DPK Bank Syariah di Indonesia oleh karena itu bank syariah harus mampu untuk menghasilkan laba yang lebih baik dari kegiatan operasionalnya serta meningkatkan pengeluaran untuk keperluan promosi. Sementara itu, faktor eksternal yaitu Bi rate justru berpengaruh negatif

Hasil penelitian ini diharapkan dapat memperkuat temuan pada penelitian penelitian sebelumnya terkait hubungan sukuk ritel dengan DPK Bank Syariah sehingga bisa dijadikan sebagai referensi bagi pihak terkait dalam merumuskan kebijakan mengenai pengembangan Industri keuangan di Indonesia secara umum. Adapun untuk penelitian kedepannya diharapkan bisa menggunakan metode empirik lainnya seperti VECM atau ARDL karena datanya merupakan time series sehingga kestasioneran data perlu diperhatikan. Selain itu, bisa juga menggunakan variabel faktor internal atau eksternal yang berbeda dengan rentang waktu yang lebih panjang sehingga bisa memberikan perspektif yang berbeda dan hasil yang lebih baik.

\section{REFERENSI}

Abduh, M., Omar, M. A., and Duasa, J. (2011). The Impact of Crisis and Macroeconomic Variables towards Islamic Banking Deposits Department of Business Administration Department of Economics, Kulliyah of Economics and Management Sciences, International Islamic University, Malaysia. 8(12), 1413-1418.

Acunto, F. D., Hoang, D., and Weber, M. (2015). Inflation Expectations and Consumption Expenditure *. February.

Afrida, Y., dan Iskandar, R. (2018). Pengaruh inflasi, kurs, tingkat suku bunga, pertumbuhan ekonomi, dan jumlah uang beredar terhadap jumlah dpk bank syari'ah yenti afrida.

Akhtar, B., Akhter, W., \& Shahbaz, M. (2017). Determinants of deposits in conventional and Islamic banking: a case of an emerging economy. International Journal of Emerging Markets, 12(2), 296-309. https://doi.org/10.1108/IJoEM-04-2015-0059.

Al-Sharif, B. M., Qwader, A., and Fattah Al-Slehat, Z. A. (2017). The Effect of Promotion Strategy in the Jordanian Islamic Banks on a Number of Customers. International Journal of Economics and Finance, 9(2), 81. https://doi.org/10.5539/ijef.v9n2p81.

Aysan, A. F., Disli, M., Duygun, M., and Ozturk, H. (2018). Religiosity versus rationality: Depositor behavior in Islamic and conventional banks. Journal of Comparative Economics, 46(1), 1-19. https://doi.org/10.1016/j.jce.2017.03.001.

Bascand, G., Browne, C., Debelle, G., Robinson, D., Samiei, H., \& Singh, A. (1997). IMF Working Paper (C) 1997. 1-25.

Dash, S. K., and Kumar, L. (2018). Does Inflation Affect Savings Non-linearly? Evidence from India. Margin, 12(4), 431-457. https://doi.org/10.1177/0973801018786155.

Demiralp, S. (2015). The rational Islamic actor? Evidence from Islamic banking New Perspectives on Turkey Perspectives on Turkey: The rational Islamic actor? Evidence from Islamic. May, 1-27. https://doi.org/10.1017/npt.2014.1

Dendawijaya, Lukman .(2009). Manajemen Perbankan. Jakarta : Ghalia Indonesia 
Kincaid, M., Jr. (2003). Promotion, Product, Service and Ideas(6th ed.). Columbus, Hoi, Bell 7, Howell Co.

Kemenkeu. (2020). Kementrian Keuangan Republik Indonesia. Retrieved Feb 20, 2020 from https://www.kemenkeu.go.id/sukukritel.

Lestari, P. (2009). Efektivitas Pengaruh Besaran Biaya Promosi Dalam Penghimpunan Dana Pihak Ketiga. Al-Iqtishad: Jurnal Ilmu Ekonomi Syariah, 1(2), 1-32. https://doi.org/10.15408/aiq.v1i2.2461.

Mimouni, K., Smaoui, H., Temimi, A., and Al-Azzam, M. (2019). The impact of Sukuk on the performance of conventional and Islamic banks. Pacific Basin Finance Journal, 54(June 2018), 42-54. https://doi.org/10.1016/j.pacfin.2019.01.007.

Mushtaq, S., and Siddiqui, D. A. (2017). Effect of interest rate on bank deposits: Evidences from Islamic and non-Islamic economies. Future Business Journal, 3(1), 1-8. https://doi.org/10.1016/j.fbj.2017.01.002.

Nachrowi, Nachrowi Djalal dan Hardius Usman. (2002). Penggunaan Teknik Ekonometri. Jakarta : PT.RajaGrafindo Persada

OJK. (2019). Otoritas Jasa Keuangan : Laporan Perkembangan Keuangan Syariah Indonesia.

Razak, S. S., Saiti, B., and Dinç, Y. (2019). The contracts, structures and pricing mechanisms of sukuk: A critical assessment. Borsa Istanbul Review, 19, S21-S33. https://doi.org/10.1016/j.bir.2018.10.001.

Rose, P and Sylvia hudgins .(2010). Bank Management and Financial Service, McGrawHill Irwin, New York, NY.

Said, M., dan Ali, H. (2016). An analysis on the factors affecting profitability level of Sharia banking in Indonesia. Banks and Bank Systems, 11(3), 28-36. https://doi.org/10.21511/bbs.11(3).2016.03.

Saunders, A. and Cornett, M.M. (2010). Financial Markets and Institutions: A Modern Perspective, McGraw-Hill Irwin, New York, NY.

Smaoui, H., and Ghouma, H. (2020). Sukuk market development and Islamic banks' capital ratios. Research in International Business and Finance, 51(17), 101064. https://doi.org/10.1016/j.ribaf.2019.101064.

Smaoui, H., Mimouni, K., and Temimi, A. (2017). Sukuk, banking system, and financial markets: Rivals or complements? Economics Letters, 161, 62-65. https://doi.org/10.1016/j.econlet.2017.09.014.

Sufian, F. (2011). Profitability of the Korean Banking Sector: Panel Evidence on BankSpecific and Macroeconomic Determinants 1 Introduction. 7(1), 43-72.

Sukmana, R. (2019). A critical assessment of retail sovereign sukuk in Indonesia. Qualitative Research in Financial Markets. https://doi.org/10.1108/QRFM-10-20180109.

Susanti, V. (2015). Pengaruh Equivalent Rate dan Tingkat Keuntungan Terhadap Dana Pihak Ketiga ( DPK ) Perbankan Syariah di Indonesia. 1(1), 113-132.

Sutono, dan Kefi, B. S. (2012). Pengaruh Faktor Makro Ekonomi Terhadap Penghimpunan Dana Pada Bank Umum di Indonesia. Jurnal EkonomiManajemen Akuntansi, 20 (4): 1-12.

Thomson Reuters and Dinar Standard. (2018). State of the Global Islamic Economy Report 2019/20. Dubai International Financial Centre, 112. https://haladinar.io/hdn/doc/report2018.pdf. 
Yaya, R., dan Sofiyana, E. (2018). Pengaruh Sukuk Ritel Pemerintah Terhadap Penghimpunan Dana Pihak Ketiga Bank Syariah. Media Riset Akuntansi, Auditing \& Informasi, 18(2), 153. https://doi.org/10.25105/mraai.v18i2.3096. 